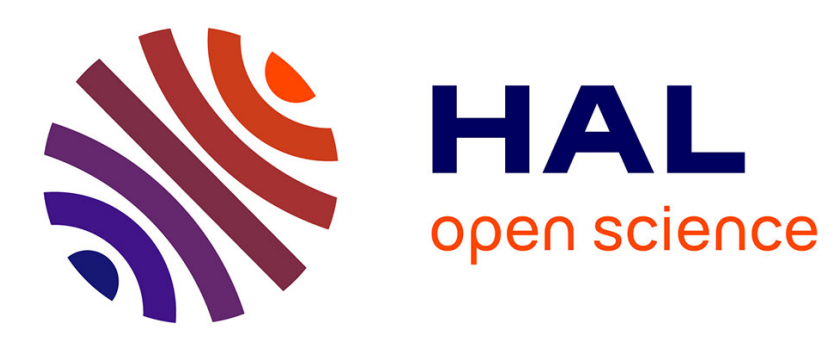

\title{
A male destroying an egg in a cooperative breeding attempt in Lesser Spotted Woodpecker
}

José Luis Romero, Sabine Mücke, Julio Pérez

\section{To cite this version:}

José Luis Romero, Sabine Mücke, Julio Pérez. A male destroying an egg in a cooperative breeding attempt in Lesser Spotted Woodpecker. Journal für Ornithologie = Journal of Ornithology, 2010, 151 (4), pp.805-809. 10.1007/s10336-010-0516-x . hal-00581015

\section{HAL Id: hal-00581015 https://hal.science/hal-00581015}

Submitted on 30 Mar 2011

HAL is a multi-disciplinary open access archive for the deposit and dissemination of scientific research documents, whether they are published or not. The documents may come from teaching and research institutions in France or abroad, or from public or private research centers.
L'archive ouverte pluridisciplinaire HAL, est destinée au dépôt et à la diffusion de documents scientifiques de niveau recherche, publiés ou non, émanant des établissements d'enseignement et de recherche français ou étrangers, des laboratoires publics ou privés. 
Title:

\title{
A male destroying an egg in a cooperative breeding attempt in
}

\section{Lesser Spotted Woodpecker Dendrocopos minor}

Names of authors: José Luis Romero, Sabine Mücke and Julio Pérez*

Affiliation: Catalan Institute of Ornithology (ICO)

Museu de Ciències Naturals (Zoologia), Passeig Picasso s/n, 08003 Barcelona, Spain

* Corresponding Author: Ed. Q (ETSE) Campus UAB, Autonomous University of Barcelona, 08193 Cerdanyola del Vallès (Barcelona), Spain; julio.perez@uab.es; phone +34 93581 2141; fax +3493581 2013

\begin{abstract}
A cooperative breeding case was found in Lesser Spotted Woodpecker (LSW) in which a male and three different females were involved. For the first time contributions of each member of the cooperative breeding team were quantified during nest excavation and incubation in LSW. During daytime, the nest was mainly occupied by the male during the final excavation phase, nest guarding and egg laying. Aggressive interactions were recorded between two of these females during nest excavation, egg laying and incubation. The male was recorded destroying an egg presumably laid by the dominant female. The highest contribution during daytime incubation was by the dominant female (39\%), followed by the male (34\%) and a second female $(27 \%)$. The third female had a very small contribution at any stage. A picture of the male removing the egg was
\end{abstract}


analyzed to estimate the egg maximum width, ruling out a possible runt egg. Motivations behind the behaviour of the male destroying the egg remained unclear.

\section{Keywords:}

Cooperative breeding, Lesser Spotted Woodpecker, Picoides minor, egg destruction

\section{Introduction}

The mating system of Lesser Spotted Woodpecker (LSW) has been previously described by Wiktander et al. (2000), Höntsch (2005) and Rossmanith (2005) as mainly monogamous but exhibiting certain tendency to social multi-nest polygamy (Wiktander, 2000; Rossmanith and Höntsch, 2009). Recently, during a study of a colour-marked population of Lesser Spotted Woodpecker (LSW) in NE Spain two cases of cooperative breeding were reported, in which two females and a male were rearing the brood in the years 2005 and 2006 (Romero and Pérez, 2008). These cases appeared in a poplar plantation in which standing dead trees were selectively logged in high percentage (about $85 \%$ ). These researchers suggested that selective logging could be understood as an (anthropogenic) ecological constraint, which could force the cooperation of the birds because of a lack of suitable nesting trees (Romero and Pérez, 2008). Among European woodpeckers regular cooperative breeders are not known, and, as far as we know, only two cases of cooperative breeding attempts have been described (besides the cases reported in LSW), (i) a male helper has been described for the Middle Spotted Woodpecker (Dendrocopos medius, Pasinelli 1993, cited in Pasinelli 2003) and (ii) a female helper Grey-headed Woodpecker (Picus canus, Südbeck and Meinecke, 1992). In the last case, the reasons why this cooperative breeding attempt appeared were associated also to ecological constraints (Südbeck and Meinecke, 1992). 
On the other hand, different cooperative breeding strategies in birds have been described based on the relative direct contribution of genes by the same-gender individuals in the breeding unit (also known as reproductive skew, Vehrencamp, 2000). When one only individual contributes genes while the others provide care, one usually uses the term helpers-at-the-nest system (also known as high skew), on the contrary when same-gender individuals have a direct contribution of genes, the term used is joint-nesting system (i.e. low skew, Vehrencamp, 2000).

We would like to briefly report a new cooperative breeding case in LSW, in which three different females and a male were involved in the breeding attempt.

\section{Methods}

The study area is located between Barcelona and Girona (NE Spain, coordinates $41^{\circ}$ $46^{\prime} \mathrm{N} 2^{\circ} 41^{\prime} \mathrm{E}$ ) and covered a surface of about $150 \mathrm{~km}^{2}$. The LSW territories are found basically in poplar (Populus x canadiensis) plantations. A more detailed description of the study area can be found elsewhere (Romero and Pérez, 2008). The specific territory where the cooperative breeding attempts appeared is also a poplar plantation, named Can Rieró. Eighty five percent of standing dead trees in this territory was logged (summer and autumn 2004). In addition, in summer 2006 about $75 \%$ of the poplar plantation was completely logged, i.e. the remaining forest surface in Can Rieró was less than 3 ha.

The individuals in the study area were marked with colour rings since 2000 following the methodology described in Wiktander (1998), for details see also Romero and Pérez (2008). The territories were visited periodically at least once per week from September to June. When nests were accessible (i.e. at a height lower than $8 \mathrm{~m}$ ) a hole was cut to ring nestlings. 


\section{Results and discussion}

Description of the cooperative breeding case (all dates in this section refer to 2007)

A non-ringed male (M, see table 1 for a description of each individual) was discovered in the Can Rieró Forest on 25 April excavating a nesting cavity from the inside. Later the same day the male was observed copulating with a ringed female (female A, FA) on a branch of the tree where the nesting cavity was being excavated. After the copulation the male and FA disappeared and a second female (female B, FB) was observed excavating inside the same cavity. On 27 April the male was observed excavating the nesting cavity and copulating with FA on a thin branch close to the cavity, in the same tree. After the copulation FA entered into the cavity and spent there nine minutes, then the male arrived to the cavity and FA flew off from it. The male entered inside the cavity and seconds later he was sticking the head out of the nest with an egg in its bill (see figure 1). After few seconds the male flew off and came back after several seconds without the egg, he entered in the nesting cavity again and continued with the excavation. Later in the morning also FB was observed inside the cavity, excavating (find a short sequence of pictures in the "Electronic supplementary material", figure I.A-H). That morning, each time FA was inside the cavity and FB was arriving to the nest, FA did not allow FB to enter. FB was only able to enter in the cavity for nest excavation when the male was inside. Sometimes FA was chasing FB to avoid her entrance inside the cavity. Similar behaviour was observed during several days. On 1 May in addition to the male, FA and FB, a third female (female D, FD) was observed entering inside the cavity. At the end of the incubation period FA disappeared and we failed, up to day, to relocate the bird. Nevertheless, none of the members of the cooperative breeding team, including the male, were calling insistently as it is a common reaction when a member of a (regular) monogamous pair disappeared due for 
instance to predation (own unpublished data). After hatching, mainly the male and FB were feeding nestlings, although we had several observations in which FD was also contributing. On 3 June the first chick was fledging. On 4 June still a nestling was inside the cavity fed by adults. A total of 44 hours of observation in 21 different days were used since 25 April until 4 June.

The nest was excavated in the main trunk of a dead Carolina Poplar (Populus $\mathrm{x}$ canadiensis) at a height of $10 \mathrm{~m}$, with the nest entrance oriented to the east. The tree had a DBH of $30 \mathrm{~cm}$.

Daytime contribution of the members of the cooperative breeding team in the different nesting stages

The daytime contribution of each member was quantified in the different breeding stages and results are presented in table 2. Male woodpeckers usually incubate and brood at night. For the purpose of comparison, however, we estimated the contribution of the members with daytime observations only. In the previously reported cooperative breeding cases in LSW poor information could be obtained for the early breeding stages (excavation, egg laying and incubation, Romero and Pérez, 2008). Therefore, this was the first time that the contribution of each team member in the early breeding stages was assessed (see table 2) for a cooperative breeding attempt in LSW. It is important to note that these two females (FA and FB) were already involved in a cooperative breeding case in 2005 (Romero and Pérez, 2008). Also interesting that FA was involved in the three cooperative breeding cases $(2005,2006$ and 2007). The dominant female (FA) was quite aggressive with FB during egg laying and incubation, this reduced the contribution of FB despite the latter insistently tried to cooperate. The contribution of FB was only possible if the male was in the cavity, given that no aggression was recorded between male and any of the females. The results of this behaviour are patent as presented in 
table 2, since FB contributed 6.1 and $26.5 \%$ in the final excavation phase and during incubation, respectively, in contrast to the higher contribution of the dominant female FA (31.9 and $39.3 \%$, respectively). This would suggest that the gametic contribution of FA is important, as concluded by Mumme et al. (1990) in their detailed studies in the Acorn Woodpecker (Melanerpes formicivorus). The third female involved (FD) had a very small contribution at any stage, if different than zero then 3.2 and $3.0 \%$ of contribution (see table 2) in the final excavation phase and during nestling feeding, respectively. Unfortunately, due to the disappearance of FA before egg hatching, and given the sporadic contribution of the third female involved (FD), we could not corroborate the trends previously reported during nestling feeding (Romero and Pérez, 2008) in which the male showed a (compensatory) reduction in nestling feeding. The male contribution is about one third $(34.2 \%)$ during incubation, when the two females (FA and FB) were recorded actively cooperating. The male contribution to nestling feeding $(54.3 \%)$ is close to the usual contribution of males in regular monogamous breeding pairs (i.e. 50\%, Wiktander et al., 2000).

\section{Egg destruction}

In cooperative breeding species when different females contribute genes often egg destruction has been described due to a competition among females to assure a high percent of contribution of their own genes in the brood (Mumme et al., 1983). This competition is also understood as a way to synchronize the brood between (among) females (Mumme et al., 1983; McRae, 1996). In this type of breeding attempts an important production of runt eggs have been detected (Koenig, 1980). Runt eggs are abnormally small and do not hatch (Koenig, 1980).

Natural examples of egg destruction by a breeder male in woodpeckers have been also described in the polygynandrous Acorn Woodpecker (Melanerpes formicivorus), 
although they are rare (Koenig 1990). Reasons for such behaviour are linked to reduced or no possibilities to parent the egg(s) destroyed (Prof. Walter D. Koenig, personal communication). In other bird species such as Common Moorhen (Gallinula chloropus), known to be predominantly monogamous but exhibiting cases of polyandry and polygyny as well as cooperative breeding with communal nesting (McRae, 1996), the male may inhibit each female's ability to interfere with the other female's reproduction (i.e., egg destruction; McRae, 1996).

Possible explanations to understand the reasons why the male removed the egg could be postulated based on previous knowledge on Acorn Woodpecker (Melanerpes formicivorus) (Prof. Walter D. Koenig, personal communication): (i) the male removed the egg under circumstances in which he was denied to access to the breeder female he felt he was entitled to; (ii) the male observed the female copulating with another male; (iii) the female came to join the nest late in the season; (iv) the male took over the nest from another male.

Since the male was inside the cavity before FA arrived and given she spent 9 minutes inside, the most likely female laying the egg is FA. In addition several copulations were observed between the male and FA (see previous sections), discarding therefore hypothesis (i). The assessment of the rest of hypothesis, (ii)-(iv) is certainly difficult, and additional information regarding previous relationships of the male with females $\mathrm{A}$, B (and D) and possibly other LSW individuals, would have been required to fully understand the motivations for such complex behaviour.

On the other hand, we would like to investigate if the removed egg was a runt egg. With this purpose, a photo of the male removing the egg from the nesting cavity was analysed (see figure 1). The averaged length of the bill of LSW males for this subspecies (i.e. $D$. minor buturlini, own unpublished data: $15.9 \pm 0.4 \mathrm{~mm},[13.9-19.6], \mathrm{n}=18$ ) was used to 
estimate the egg maximum width as $15.6 \mathrm{~mm}$. Due to the angle in which the photo was taken, together with the position of the egg, only the egg maximum width can be estimated with certain precision. This eliminates the possibility to obtain an accurate estimation of the volume, given that the maximum length of the egg can not be known. We compared the estimated value with the average maximum width of LSW eggs for (i) our own unpublished measurements of an abandoned nest $(14.1 \pm 0.4 \mathrm{~mm} ; \mathrm{n}=5$ of the same clutch) and (ii) with the average found elsewhere (15 mm, [13-16], n=100, Cramp, 1985). Therefore, our estimation would indicate that the egg was a normal egg and not a runt one. Direct measurement of all eggs of the clutch, including the one removed, will have been the more reliable way to discard a possible runt egg, given that runt eggs are not always evident to separate from normal ones (Koenig, 1980). In fact, Koenig (1980) studied the variations in egg dimensions in case of runt eggs but he used volume rather than absolute variations in dimensions as the best way to separate runt eggs from normal ones.

\section{Zusammenfassung}

\section{Ein männlicher Kleinspecht Dendrocopos minor zerstört ein $\mathrm{Ei}$ in einem gemeinschaftlichen Brutversuch}

Bei Kleinspechten wurde ein Fall von gemeinschaftlicher Brut beobachtet, an dem ein Männchen und drei Weibchen beteiligt waren. Zum ersten Mal bei Kleinspechten konnten die Beiträge der Individuen zu Nestbau und Bebrütung zahlenmäßig erfasst werden. Während des Nestbaus, der Bewachung des Nestes und der Legephase wurde das Nest tagsüber hauptsächlich vom Männchen besetzt. Zwischen zwei der Weibchen kam es während des Nestbaus, der Eiablage und der Bebrütung zu aggressivem Verhalten. Das Männchen zerstörte nachweislich ein Ei, das vermutlich vom dominanten Weibchen stammte. Die Bebrütung tagsüber wurde zum größten Teil vom dominanten Weibchen übernommen (39\%), gefolgt vom Männchen (34\%) und einem 
zweiten Weibchen (27\%). Der Beitrag des dritten Weibchens war insgesamt sehr gering. Anhand eines Fotos davon, wie das Männchen das Ei entfernte, konnte die maximale Breite des Eis festgestellt werden. Somit wurde ausgeschlossen, dass es sich um ein Zwergei handelte. Die Ursachen für das Verhalten des Männchens bleiben unklar.

\section{Acknowledgements}

We would like to thank the direct support of this research by the Catalan institution Fundació Caixa de Catalunya (Area Territori i Paisatge). The authors would like to thank Dr. Martjan Lammertink (Cornell Laboratory of Ornithology, Cornell University, Ithaca, NY, USA) for advice and help with regards to the course of the research; Prof. Walter D. Koenig (Cornell Laboratory of Ornithology, Cornell University, Ithaca, NY, USA) for discussion and valuable hypothesis regarding the possible reasons behind the behaviour of the male during the cooperative breeding case. We would like to acknowledge as well the help of Peter Südbeck, Hans Winkler, Ulf Wiktander, Hugo Robles, Eva Rossmanith, Jose Luis Copete, Marta Pascual, Francesc Macià, Raül Aymí, Sergi Ricart and Ramon Sanz. All of the manipulations of birds performed during this study comply with the current laws of the country in which they were performed.

\section{References}

Cramp, S. (1985) Handbook of the Birds of Europe and the Middle East and North Africa. Oxford University Press, Oxford, UK.

Höntsch K (2005) Autokölogie einer bestandsbedrohten Vogelart im hessischen Vordertaunus. PhD Thesis, Johann Wolfgang Goethe-Universität Frankfurt, Frankfurt, Germany.

Koenig WD (1980) The determination of runt eggs in birds. Wilson Bull 92(1):103-107. 
Koenig WD (1990) Opportunities of parentage and nest destruction in polygynandrous acorn woodpeckers, Melanerpes formicivorus. Behav Ecol 1:55-61.

Koenig WD, Mumme RL, Stanback MT, Pitelka FA (1995) Patterns and consequences of egg destruction among joint-nesting acorn woodpeckers. Anim Behav 50:607-621. McRae SB (1996) Family values: costs and benefits of communal nesting in the moorhen. Anim Behav 52:225-245.

Mumme RL, Koenig WD, Pitelka FA (1990) Individual contributions to cooperative nest care in the Acorn Woodpecker. Condor 92:360-368.

Mumme RL, Koenig WD, Pitelka FA (1983) Reproductive competition in the communal Acorn Woodpecker: sisters destroy each other's eggs. Nature 306:583-584.

Romero JL, Pérez J (2008) Two cooperative breeding cases in Lesser Spotted Woodpecker Dendrocopos minor. J Ornithol 149:67-74.

Rossmanith E (2005). Breeding biology, mating system and population dynamics of the Lesser Spotted Woodpecker (Picoides minor). PhD Thesis, Universität Postdam, Postdam, Germany.

Rossmanith E, Blaum N, Höntsch K, Jeltsch F (2009) Sex-related parental care strategies in the lesser spotted woodpecker Picoides minor: of flexible mothers and dependable fathers. J Avian Biol 40: 28-33.

Südbeck P, Meinecke H (1992) Grauspecht-Weibchen Picus canus als Helfer an der Bruthöhle. J Ornithol 133:443-446.

Vehrencamp SL (2000) Evolutionary routes to joint-female nesting in birds. Behav Ecol 11(3):334-344.

Wiktander U (1998) Reproduction and survival in the Lesser Spotted Woodpecker. Effects of life history, mating system and age. Ph.D. Thesis, Lund University, Lund, Sweden. 
Wiktander U, Olsson A, Nilsson SG (2000) Parental care and social mating system in the Lesser Spotted Woodpecker Dendrocopos minor. J Avian Biol 31:447-456. 
Table 1.- Basic description of the four individuals involved in the new cooperative breeding case found in 2007. Photos of each individual during nesting period are presented in the "Electronic supplementary material", figure II. Rings colour code: MX (right tarsus), $\mathrm{XY}$ (left tarsus); $\mathrm{M}=$ metallic; $\mathrm{P}=$ pink; $\mathrm{O}=$ orange; $\mathrm{G}=$ light green; $\mathrm{D}=$ dark green; $\mathrm{W}=$ white; $\mathrm{B}=\mathrm{blue} ;$ * ringed as nestling.

\section{Rings Ringing data:}

\begin{tabular}{llccc} 
Individual & Age & colour code & euring age (date) & Role description \\
\hline Male & Unknown & No rings & No rings & Breeder \\
Female A & $5^{\text {th }}$ year & P,PO & $5(4 / / / 2004)$ & Breeder, dominant \\
Female B & $3^{\text {rd }}$ year & G,GD & $1^{*}(22 / \mathrm{V} / 2004)$ & Breeder? \\
Female D & Unknown & No rings & No rings & Helper? \\
\hline
\end{tabular}


Table 2.- Daytime contribution of the individuals (percentage \pm standard error of the mean) involved in the cooperative breeding case in the different breeding stages. Final excavation phase - Nest guarding - Egg laying (period sampled since 25 April until 2 May); incubation (period sampled since 4 May until 11 May); nestling feeding (period sampled since 13 May until 3 June). Contributions were estimated each different day of observation and $\mathrm{n}$ indicates de number of days sampled to obtain the average. The observation time per day habitually was 2 hours.

\begin{tabular}{lcccc} 
Stage & MA & FA & FB & FD \\
\hline Final excavation phase - & $\begin{array}{c}58.7 \pm 3.8 \\
(n=4)\end{array}$ & $\begin{array}{c}31.9 \pm 4.4 \\
(n=4)\end{array}$ & $\begin{array}{c}6.1 \pm 2.9 \\
(n=4)\end{array}$ & $\begin{array}{c}3.2 \pm 3.2 \\
(n=4)\end{array}$ \\
Nest guarding - Egg laying & $\begin{array}{c}34.2 \pm 7.4 \\
(n=3)\end{array}$ & $\begin{array}{c}39.3 \pm 9.0 \\
(n=3)\end{array}$ & $\begin{array}{c}26.5 \pm 2.8 \\
(n=3)\end{array}$ & $0(n=3)$ \\
Incubation & $\begin{array}{c}54.3 \pm 0.5 \\
(n=12)\end{array}$ & $0(n=12)$ & $\begin{array}{c}42.7 \pm 0.3 \\
(n=12)\end{array}$ & $\begin{array}{c}3.0 \pm 0.2 \\
(n=12)\end{array}$ \\
Nestling feeding & & & & \\
\end{tabular}




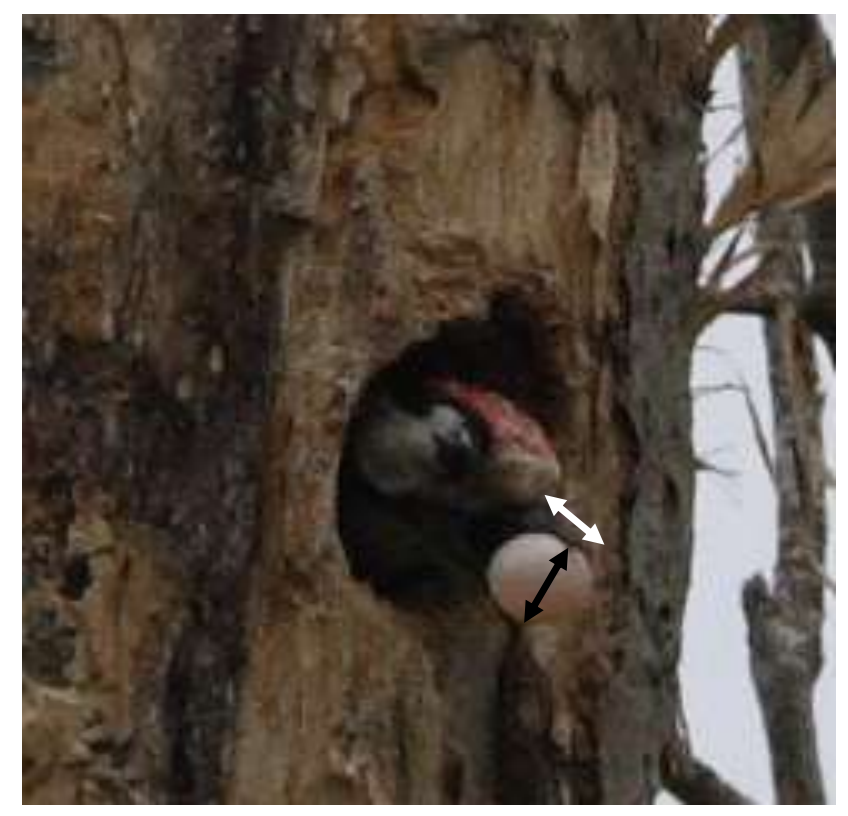

Figure 1. Male removing an egg from the nest, presumably laid by FA. Arrows indicate the length of the bill and the egg maximum width (white and black, respectively). Average bill length measured for D. minor buturlini was used to estimate the egg maximum width. 